\title{
Running the Numbers for the Path of Mantra: Distinguishing the Thirteenth Bhūmi in Fifteenth-Century Tibet
}

\author{
Rae Dachille
}

check for

updates

Citation: Dachille, Rae. 2021.

Running the Numbers for the Path of

Mantra: Distinguishing the

Thirteenth Bhūmi in

Fifteenth-Century Tibet. Religions 12:

175. https://doi.org/10.3390/

rel12030175

Academic Editor: Glen A. Hayes

Received: 31 January 2021

Accepted: 3 March 2021

Published: 9 March 2021

Publisher's Note: MDPI stays neutral with regard to jurisdictional claims in published maps and institutional affiliations.

Copyright: (C) 2021 by the author. Licensee MDPI, Basel, Switzerland. This article is an open access article distributed under the terms and conditions of the Creative Commons Attribution (CC BY) license (https:// creativecommons.org/licenses/by/ $4.0 /)$.
Department of Religious Studies and Classics and East Asian Studies, University of Arizona, Tucson, AZ 85721, USA; raedachille@email.arizona.edu

\begin{abstract}
This article explores a Buddhist text in which numbers set the very stakes for liberation In 1404, Ngor chen Kun dga' bzang po (1382-1456), who was to become one of the most esteemed tantric commentators of the Tibetan Sakya tradition, composed his first polemical text, Dispelling Evil Misunderstandings of the Explanation of the Ground of Zung 'jug Vajradhara. In this early work, Ngor chen grapples with the relationship between the path of perfections and of secret mantra as conduits to liberation. I illuminate the ways in which ritual, exegesis, and pedagogy converge in Ngor chen's text to reveal larger implications for distinguishing the eleventh and thirteenth grounds (bhümi) of Buddhahood in fifteenth-century Tibet. In concluding, I highlight the art of differentiation as a fundamental Tibetan scholastic enterprise and briefly engage Ngor chen's acts of distinguishing sūtra and tantra in conversation with those of key Tibetan predecessors and contemporaries.
\end{abstract}

Keywords: Tibetan Buddhism; tantra; Sakya; Ngor chen; bhūmis; Red mda' ba; Vajradhara; zung 'jug; Guhyasamāja; Buddhist polemics

\section{Introduction}

This article explores a Buddhist text in which numbers set the very stakes for liberation. In 1404, Ngor chen Kun dga' bzang po (1382-1456), who was to become one of the most esteemed tantric commentators of the Tibetan Sakya tradition, composed his first polemical text, Dispelling Evil Misunderstandings of the Explanation of the Ground of Zung 'jug Vajradhara. ${ }^{1}$ In this early work, Ngor chen grapples with the relationship between the path of perfections and the path of secret mantra as conduits to liberation. He sets out to refute the claim that the surramgama samādhi of the path of perfections and the state of "union" (zung 'jug Skt. yuganaddha), the ultimate goal of tantric practice, are identical. Ngor chen combines enumeration and citation as tools for articulating crucial distinctions between the attainments of the tenth through thirteenth grounds. In this text, numbers signal a shift in which mapping the path to liberation is not only descriptive and prescriptive but also polemical.

The Buddha's eightfold path is more of a holistic system of practices of cultivating body, speech, and mind than a chronological progression to a goal. However, the paths and grounds model is one of many that translate mapping liberation into counting and stratifying levels of attainment. Mahāyāna authors distinguish the altruistic motivations of the bodhisattva as superior and deploy the bhūmi model to elevate the attainment of the bodhisattva above that of the arhat. According to this model, the practitioner advances through ten grounds or stages of perfecting the qualities of the bodhisattva before attaining buddhahood. The trajectory for a Mahāyāna practitioner suggests it will take an infinite number of lifetimes to reach this final goal. The Vajrayāna path offers the promise of

1 (Ngor chen) Kun dga' bzang po (1382-1456), Dispelling Evil Misunderstandings of the Explanation of the Ground of Union Vajradhara (Zung 'jug rdo rje 'chang chen po'i sa mtshams rnam par bshad pa log rtod ngan sel), in Gsung 'bum: Kun dga' bzang po. Ngor chen kun dga' bzang po'i bka' 'bum. Compiled by Bsod nams rgya mtsho and reproduced from the Sde dge block prints. Dehra dun: photomechanical print from a set of prints from the Sde dge dgon chen blocks. BDRC W1157. vol. 1, pp. 659-91. 
attaining enlightenment in this lifetime and this body. Empowered through ritual practice, tantric practitioners correlate humans and buddhas through elaborately choreographed acts of imagination known as sādhana. Ngor chen's text is one attempt to "run the numbers" for the Vajrayāna approach.

For Ngor chen, the best of buddhas is one with nothing more to learn and of whom there is nothing higher. In the broadest sense, a Buddha is an awakened being who has "done what is to be done" and is "thus gone," free from the karmic destiny of continued cycling through the endless phases of death and rebirth. As Buddhist traditions evolve, the possibilities for what enlightenment looks like increase. Consequently, authors assert distinctions between different types of Buddhahood, such as "perfected" and "fully perfected." The form of Mahāyāna Buddhism that entered Tibet around the eighth century was deeply infused with Vajrayāna elements. As these two vehicles to enlightenment continued to evolve in relationship to one another on Tibetan soil, their respective views of the fruition of Buddhahood sparked efforts of synthesis and differentiation. In this article, I highlight a connection between the discourses around being beyond learning (mi slob Skt. aśaikșa) with the state of not possessing something higher (gong na med) in Ngor chen's texts. In the process, I identify a particular configuration of socio-political, pedagogical, ritual, and exegetical factors that made it essential for Ngor chen to distinguish the eleventh and thirteenth grounds, the fruits of sūtra and tantra, respectively, in early fifteenth-century Tibet.

Ngor chen composes this text twenty-five years before founding Ngor monastery, at the very beginning of what was to be a prolific career of composing tantric treatises. ${ }^{2}$ Over time, Ngor chen develops his prowess in articulating the distinct exegetical and ritual dimensions of the Sakyapa tantric perspective in tension with the emerging Gandenpas. Ngor chen's later tantric polemics have sparked recent scholarly interest. However, this early text, briefly described by Davidson as a "defense of the superiority of the Vajrayāna enlightenment," has received little attention to date (Davidson 1991, p. 221). ${ }^{3}$

\section{Results}

Ngor chen's text reveals a moment in which shifts in practices of differentiating the paths and fruits are linked to efforts to differentiate traditions. Ngor chen is building upon a legacy of venerable Sakya predecessors such as Bsod nams rtse mo (1142-1182) and Sa skya Pandita kun dga' rgyal mtshan (1182-1251) (Sa pan), who undertook large projects of classifying the vehicles of Buddhist practice and their associated texts. I argue that while Ngor chen's approach fits into a larger history of tantric authors asserting or defending claims for the legitimacy and even superiority of the Vajrayāna path, his argument is also particular to the early fifteenth-century moment in Tibet. His text reveals subtleties in the configuration of tantra and scholasticism before the time of iconic figures such as Go rams pa bsod nams seng ge (1429-1489) and Shākya mchog ldan (1428-1507), both of whom were his students. ${ }^{4}$ Ngor chen's interpretive maneuvers suggest ways of enriching evolving scholarly engagements with the work of these later Sakyapa authors as well with his own later polemical enterprises.

I begin by briefly summarizing the main issues at stake in the text and contextualizing this work within the early fifteenth-century moment. In the process, I consider why it would be necessary for Ngor chen to reinforce the idea of the tantric path as both different and better than the path of perfections. I then examine his argument more closely, focusing on one particular section in which the concerns with pathways to liberation and classificatory schema converge in an intriguing way. In the process, I show how Ngor chen connects debates around the category of mi slob or "beyond training" to a network of related

2 For an extensive study of Ngor chen's life, including inventories of his textual production, see (Heimbel 2017).

3 More recently, Heimbel also mentions this text briefly in his chapter on "Ngor chen's Involvement in Religious Disputes." See (Heimbel 2017, p237 $\&$ p239 fn141).

4 On Gorampa, see (Go-rams-pa Bsod-nams-sen-ge et al. 2007); (Ngawang Jorden 2005); and (Kassor 2011). On Shakya Chogden, see works by Komarovski, including (Komarovski 2011). 
concerns with "not possessing something higher" (gong na med or bla na med). Through examining one citation Ngor chen uses in this text and then again in a tantric polemical text he wrote just two years later, I show how ritual, exegesis, and pedagogy converge to reveal larger implications for distinguishing the fruits of sūtra and tantra. In the final section, I highlight the art of differentiation as a fundamental Tibetan scholastic enterprise and briefly engage Ngor chen's acts of distinguishing sūtra and tantra in conversation with those of key Tibetan predecessors and contemporaries.

\section{Discussion}

\subsection{The Śūramgama Samādhi Is Not zung 'jug}

Ngor chen argues that his opponent's claim that the suuramgama samādhi is equivalent to the zung 'jug of mantra is faulty. His opponent correlates these states on the basis of a particular reading of Āryadeva's writings. Āryadeva cites the Sūraṃama Samādhi Sūtra in the first chapter of his Caryā-melāpaka-pradīpa (CMP), referenced in an abbreviated way by Tibetan authors as the spyod bsdud, a canonical work of the Ārya Guhyasamāja tradition. ${ }^{5}$ Some Tibetans equated Āryadeva with the central Madhyamaka author of the same name in creating the lineage known in Tibet as the Ārya Guhyasamāja. In the sūtra passage, the Bhagavan instructs the bodhisattva Dṛ̣hamati in achieving the sunramgama samādhi using the metaphor of the student of archery who learns to hit progressively more precise targets, beginning with a mound of earth and culminating in a tiny fraction of a hair. The metaphor presents a gradual process of increasing focus that results in the ability to target "any being." Of course for the bodhisattva to hold a being in the cross-hairs is to ensure their ability to rescue sentient beings from suffering. The precision they have honed has pedagogical and salvific implications.

The sūtra identifies this bodhisattva who has attained śūramgama samādhi as one who has attained the tenth ground and as one "with nothing more to learn." 6 Discourses of being beyond learning ( $m i$ slob Skt. aśaikṣa) display competing ideas of the ultimate goal or fruit of Buddhist practice. The Mahāyāna formulation of aśaikṣa describes the state of the adept who has attained Buddhahood, having advanced through a series of ten stages or "grounds" (sa Skt. bhümi) and perfected ten corresponding qualities of the bodhisattva, beginning with generosity and culminating in knowledge. (Gethin 1998, p. 196). The Sarvāstivādin tradition identifies the state of being beyond learning with the figure of the arhat, the ultimate of four fruits of practice; progressing through the paths of seeing and cultivation, the final fruition of liberation as an arhat is the aśaikṣamārga. (Dhammajoti 2015, p. 440). ${ }^{7}$ After attaining the adamantine samādhi, adepts of all three paths of the śrāvaka, pratyekabuddha, or bodhisattva, completely destroy the fetters binding them within samsāra (in some cases, also seeing for themselves that the ties that bind are decimated); this point of liberation whether as an arhat or buddha marks the summation of the path upon which there is "nothing more to learn." (Buswell and Lopez 2013). Ngor chen's text attests to a need to make sense of how the state of being beyond learning translates to the goals of Vajrayāna practice.

Ngor chen accuses his opponent of confusing the state of sūramgama samādhi with that of zung 'jug (Skt. yuganaddha). Āryadeva identifies both with mi slob in the CMP. In part, Ngor chen's argument is exegetical, concerned with interpreting two different contexts Âryadeva uses to describe what it means to be "beyond learning." According to Ngor chen, context allows for these two different modes of describing mi slob; there is no internal contradiction (nang 'gal) in Āryadeva's writings.

5 Tshul khrims rin chen, "Spyod pa bsdus pa'i sgron ma," in bstan 'gyur (sde dge). TBRC W23703. 35: 115-214. Delhi: Delhi karmapae choedhey, Gyalwae sungrab partun khang, 1982-1985. For a study and translation of this text, see (Wedemeyer and Āryadeva 2007).

6 For a translation and study of the sūtra, see (Lamotte et al. 2003). Drewes describes the suuramgama samādhi as a state manifested by tenth ground bodhisattvas enabling them to remain bodhisattvas and still in a sense be buddhas and to die without entering nirvāna. (Drewes 2018, p. 82).

7 I am grateful to Alexander von Rospatt for bringing Dhammajoti's text to my attention as well as for sharing his thoughts on the category of aśaikṣa. 
The category of zung 'jug includes rich associations in Buddhist texts, many of them revolving around ideas of uniting different varieties of experience. ${ }^{8}$ These include:

- The union of calm and insight;

- A particular understanding of the relationship of two truths;

- *A special kind of "buddha";

- $\quad$ * In the Guhyasamāja cycle, the fifth of the five stages in Nāgārjuna's Pañcakrama;

- $\quad$ "the union of clarity and emptiness" (gsal stong zung 'jug).

I have chosen to retain the Tibetan term here in light of the polysemy of zung 'jug in Tibetan discourses. ${ }^{9}$ While I will gesture toward the principle of gsal stong zung 'jug later in this article, in a brief comparison with another tantric polemical text authored by Ngor chen, I mostly bracket the rich discussions of this principle in Path and Fruit literature, particularly within the writings of Sakyapa and Kagyupa authors, for future investigations. I have marked the two meanings that are most relevant for the present study of Ngor chen's text with asterisks. The first of these indicates a special kind of buddha, a kind of googol of a Buddha, unsurpassable in every regard. The second refers to the culminating stage of the Guhyasamāja practice.

In the context of Āryadeva's CMP, the stage of zung 'jug (zung du 'jug pa'i rim pa) refers to the ultimate samādhi. ${ }^{10}$ After the progressive purification of the body, speech, and mind through the phases of "isolation" (dben Skt. viveka) and the realization of conventional and ultimate reality, the practitioner attains this profound level of realization. Chapter one of Āryadeva's text concludes with the comparison of the states of śuramgama samādhi and zung 'jug in terms of the quality of being "beyond learning." Wedemeyer translates the passage as follows:

"When, having arisen through the process of gnosis, the self that is the prototypical brilliance is perfectly enlightened by making the two realities nondual, one has learned the perfection samādhi.

A (great) yogin equipoised in the perfection samādhi learns nothing (further). Why so? For it is well-learned previously; just as the archery master who can (find his mark) by sound alone learns nothing (further). Why? Because it has been well-learned previously, it becomes manifest through the force of that one's prior impetus. Likewise, one who is established in the perfection samādhi has nothing (further) to learn, for it was (extremely) well-learned previously. The transcendent and worldly accomplishments (siddhi) of that one manifest effortlessly." (Wedemeyer and Āryadeva 2007, pp. 147-48).

Awakening is a beginning rather than an end, the beginning of a new phase of salvific activity in the world. Achieving a state of being one "with nothing more to learn" does not mean one is "done" with the project of salvation, neither for the supreme archer of the Sūramgama Samādhi Sūtra nor for the practitioner who has attained zung 'jug. The individual who attains each of these states has put in the work that now produces an effortless performance of Buddhahood. The Sūramgama Samādhi Sūtra describes a bodhisattva capable of negotiating paradox in a quintessentially Mahāyāna way. They "manifest Paranirvāna, without definitively ceasing to be," traverse buddha fields without "conceiving" of them, and make distinctions when necessary without adhering to them in any fundamental way. (Lamotte et al. 2003, p. 113). As a skilled teacher, they penetrate the minds of sentient beings in order to guide them in attaining the adamantine samādhi. ${ }^{11}$

8 These meanings of yuganaddha as "yoked together," "union," and "joining," share a quality of bringing together two members of a set (Buswell and Lopez 2013, p. 1042). In additional to meanings within tantric literature, Buswell and Lopez provide instances from the Pāli treatises in which yuganaddha indicates the way in which the practitioner unites samatha and vipassana by 'alternating' between them. Thurman proposed "communion" as a viable translation of the term in the tantric context of the Guhyasmāja. For a critique of this choice, see (Tomabechi 2000).

9 Zung 'jug (yuganaddha) displays a diverse range of precise technical meanings within different tantric cycles. For an astute discussion of polysemy in tantric literature, see (Davidson 2002).

10 For a useful chart envisioning zung 'jug's place within the larger context of the Guhyasamāja practice, see (Wedemeyer and Āryadeva 2007, p. 83). On the terminology, see p148 fn46.

11 For a description of this bodhisattva in terms of the "Hundred Aspects of the Heroic Progress," see (Lamotte et al. 2003, pp. 119-26). This bodhisattva is capable of manipulating form and evening of transforming their sex. 
Ngor chen cites Nāgārjuna's Pañcakrama, an Ārya Guhyasamāja text on the completion stage sādhana, and its commentary to reinforce that the zung 'jug samādhi is the mark of one who requires no more training, does not differentiate between conventional and ultimate, uniting that which is with and without aspects, binding and mixing (bcings shing 'dres par). This yogin "arises as if waking from sleep." ${ }^{12}$ Yet, they are able to walk and chew gum at once. This yogin retains their one-pointed focus while moving on to teach for as long as samsāra endures. They actualize the fruit ('bras bur gyur ba'i nges par), attaining the wisdom of the dharmadhātu. Thus, they are one with nothing more to learn, the ultimate point (mthar thug pa).

Ngor chen punctuates his critique of the conflation of sūramgama samādhi with zung 'jug with Āryadeva's own words: "Thus from a distinct cause, a distinct fruit comes about." 13 The language of the cause and fruit, familiar from broader Buddhist accounts of causality, resounds with Tibetan discourses on tantric causality such as the use of sādhana to produce a "similar type cause" for producing a Buddha body as well as with the Path and Fruit's approach to the existence of the result in the path. Who or what is prompting Ngor chen to differentiate the fruits of sūtra and tantra?

\section{2. "Systematizer"}

Ngor chen's opponent in this text (or at the very least one of his opponents) is Red mda' ba, a Sakyapa master perhaps best known as teacher to Tsongkhapa. The offensive remarks appear in Red mda' ba's commentary on Candrakirti's Pradīpoddyotana (Tib. sgron gsal), another one of the core texts of the Ârya Guhyasamāja system. ${ }^{14}$ Red mda' ba composed the Yid kyi mun sel over a decade before Ngor chen composed his rebuttal. This delayed reaction in not unusual in the Tibetan context, in which polemical responses sometimes fail to emerge for hundreds of years. The fact that Ngor chen composed his critique during Red mda' ba's lifetime indicates the proximity of issues of inter-relationship and lineage percolating in the background.

The Guhysamāja cycle assumed an intensified potency in the tantric polemics of the early fifteenth century, with pronounced implications for ritual, exegesis, and lineage. In 1390, after encountering resistance at Sa skya, Red mda' ba headed into retreat in Gangs $\mathrm{bu}$, and during that retreat, he composed his approximately 750 folia-side compendium on the Guhyasamāja system. ${ }^{15}$ In 1404 , Red mda' ba was once again in retreat (1402-1405) when Ngor chen wrote Dispelling Evil Misunderstandings of the Explanation of the Ground of Zung 'jug Vajradhara. In the same year, Tsong kha pa composed his commentary on the Samāja-sādhana-vyavasthāli in which he critiques Red mda' ba's interpretation of key aspects of the Guhyasamāja practice. Yael Bentor has shown how on several points of ritual interpretation, Red mda' ba follows the eleventh-century master 'Gos Khug pa lhas btsas rather than Bu ston; this interpretive choice becomes a point of contention between him and Tsong kha pa. ${ }^{16}$ In directing his polemical energies toward Red mda' ba, Ngor chen enters into this web of charged discourses on the Guyasamāja as a ritual and textual system with the potential to sustain debate on the relationship of sūtra and tantra as well as between individuals and traditions.

Systematization is certainly in the air in this early fifteenth century moment, and the classification and correlation of the paths of sūtra and tantra proves to be fertile terrain for Tibetan scholasticism and polemics. For example, in 1402, just two years before Ngor chen

12 The commentary referred to here is from Nāgabodhi's commentary: Tshul khrims rin chen, "Rim pa lnga pa'i bshad pa nor bu'i phreng ba," in bstan 'gyur (sde dge). TBRC W23703. 37: 29-315. Delhi: Delhi karmapae choedhey, gyalwae sungrab partun khang, 1982-1985. See 120-21 for relevant section. For Ngor chen's citation, see Ngor chen, Dispelling Evil Misunderstandings of the Explanation, 677.1-677.3.

13 Ngor chen, Dispelling Evil Misunderstandings of the Explanation, 672.6.

14 (Red mda' ba) Gzhon nu blo gros, “Dpal gsang ba 'dus pa'i 'grel pa sgron ma gsal ba dang bcas pa'i bshad sbyar yid kyi mun sel zhes bya ba'i legs bshad rgya mtsho'i tshogs," in Gsung 'bum: Gzhon nu blo gros. TBRC W23629. 3: 7-760. (Kathmandu): Sa skya rgyal yongs gsung rab slob gnyer khang/, 1999. I refer to Red mda' ba's text throughout this article as the Yid kyi mun sel.

15 For a rich inquiry into Red mda' ba's life and works, see (Roloff 2009, p. 6).

16 The potential of the Guhyasamaja sadhana as a tool for recreating one's reality and purifying the stages of death, bardo, and rebirth were especially at stake in these differing interpretations. See (Bentor 2016, pp. 109, 115, and 118). 
composed this text, Tsong kha pa wrote his epic Lam rim chen mo, and in 1405, its tantric counterpart, the Sngags rim chen mo. (Repo 2021). Bentor characterizes both Tsong kha pa and Ngor chen as "systematizers" with a shared concern of "distancing themselves from several of their Indian and Tibetan predecessors" (Bentor 2017, p. 229). I have suggested elsewhere that Red mda' ba's position as a point of overlap or site of cross-contamination of the Sakyapa and emerging Gandenpa lineages, produced anxiety not only for Tsong kha pa and his disciples but also for Sakyapas of the time. (Dachille 2019). I argue that appreciating the subtleties of "sectarian differentiation" in early fifteenth-century Tibet involves observing how both Tsong kha pa and his disciples as well as Sakyapa authors not in his lineage differentiate their interpretations from those of Red mda' ba.$^{17}$

\section{3. "No More Training" and "Nothing Higher"}

Ngor chen asserts his position as identical to that of the Sakyapa forefathers and the Indian scholars. ${ }^{18}$ The buddha of the perfections attains the eleventh ground, while the buddha of mantra is the thirteenth ground zung 'jug Vajradhara. He describes the Tathāgata of the perfections, of the eleventh ground, as one who has united appearance and wisdom and realized their emptiness. What's lacking for this buddha is knowledge of mahāmudra; without knowing mahāmūdrā, one can be a buddha but not a yogin. One who obtains the thirteenth ground of Vajradhara is unique in engaging a different perspective on desire and other poisons. Ngor chen illustrates this mental attitude with a metaphor of a special elephant. Whereas a common elephant eats the ketaki flower and produces dung, there is the exceptional elephant who transforms it into musk. Likewise by engaging with desire through a superior attitude ('dod chags la sogs pa bsam pa'i khyad pa), the practitioner generates a superior fruit (khyad par can gyi 'bras bu). ${ }^{19}$

In the final section of his text, Ngor chen casts off potential objections to his position. ${ }^{20}$ He clearly states that in order to attain zung "jug Vajradhara, the "proximate cause" (nye rgyu) is necessary. The implication is that sexual yoga with the consort is vital to attaining the goal. If one enters the Vajrayāna after the tenth ground, it's possible to instantly traverse the eleventh and twelfth along with the lower half of the thirteenth. Only after that does one achieve the ground of Vajradhara. Ngor chen draws upon a tantricized account of the Buddha's enlightenment to explain that process of casting off (dor bar) inferior meditative states for a superior method. This is a broader trope in Buddhist accounts of meditative absorption, of letting go of blissful states that threaten to impede further soteriological progress if mistaken for the final goal. Tantric authors manipulate this trope further to explain the connection of the paths of sütra and tantra as well as to posit the necessity of the Vajrayāna initiations. ${ }^{21}$ In the example, which Ngor chen identifies as the Pañcakrama's explanation of the intention of the Lalitavistara, buddhas congregating in the sky above the soon-to-be Buddha warn him to snap out of it. ${ }^{22}$ Snapping their fingers, they warn Saakyamuni not to mistake an inferior meditative state for the ultimate (mthar thug) goal. They instruct him to visualize the clear light, empowering his vajra body, and with that he abandons (btang) the unshakeable samādhi. Ngor chen also cites a commentary which more explicitly details how the buddhas empower Śākyamuni, making him a fit vessel (snod $d u$

17 In his work on philosophical exchanges involving Ngor chen's student Go rams pa, Cabezón introduced the term "sectarian differentiation" to push back against scholarly tendencies to use "sectarianism" to interpret polemical exchanges within Tibetan scholasticism in reductionist ways (Go-rams-pa Bsod-nams-sen-ge et al. 2007, p. 7).

18 For the section of Ngor chen's text in which he lays out the views of his own tradition (rang lugs bzhag), see Ngor chen, Dispelling Evil Misunderstandings of the Explanation, 674.4-677.6. The texts adheres to a common triadic polemical formula known in Tibetan as dgag bzhag spong, first laying out the objectionable view, then establishing one's own position, and finally casting off potential objections.

19 Ngor chen refers to the source of this citation as simply the rgyud phyi ma. It appears within the Yang dag par sbyor ba'i thig le of the Sge dge bka' 'gyur. For the section citing the metaphor of the elephant, see Ngor chen, Dispelling Evil Misunderstandings of the Explanation, 676.1-676.5.

20 For this section of Ngor chen's text in which he casts off objections (rtsod pa spong ba), see Ngor chen, Dispelling Evil Misunderstandings of the Explanation, 677.6-691.3.

21 For an illuminating study of the intersection of narrative and ritual in Indian tantric accounts of the Buddha's enlightenment, see (Dalton 2019).

22 See Ngor chen, Dispelling Evil Misunderstandings of the Explanation, 682.6-683.3. 
rung bar byas) to receive the tantric teachings. ${ }^{23}$ These luminaries urge the buddha-to-be to recognize that his meditative attainment is not the attainment of the ultimate ( $m$ thar thug thob byed) or the perfection of the final stage (rdzogs pa'i rim pa'i pha rol tu phyin pa). It is not the "attainment of the spontaneous generation of suchness by clarifying and the nature of joy," meaning he lacks the experience of tantric practice with a consort. ${ }^{24}$ Casting off (bor) the inferior samādhi, Sākyamuni attains the fourth oral instruction.

As a scholar interested in connections of ritual and exegesis in Tibetan texts, I find this section of Ngor chen's argument especially intriguing in bringing soteriology and doxography into contact. Scholars of Buddhist studies, such as Buswell, Gimello, Dalton, and Harter, have fruitfully interrogated these terms to determine their usefulness in the Tibetan and broader Buddhist context. (Buswell and Gimello 1992; Dalton 2005; Harter 2011). I enter into this conversation by highlighting the ways in which discourses on the pathways to liberation and on the classification of texts and views intersect in Ngor chen's argument.

Mārga discourses in Buddhism have repeatedly addressed similar challenges to account for what came before. Ngor chen provides one example of how the construction of paths to Buddhahood is linked to the task of differentiation. For example, an imagined interlocutor suggests that the lower yoga tantras teach the union of emptiness and compassion and are therefore equivalent (mtshungs par) to zung 'jug. Ngor chen responds with a comparison that highlights the existence of vital distinctions (khyad par yod pa). Ngor chen suggests that just as the śravakayāna teaches the qualities of a Buddha but lacks teachings on emptiness and is therefore distinct from the Mahāyāna, so the lower tantras (rnal 'byor rgyud man chad), the yoga, caryā and kriyā, teach the bliss of Buddhahood but lack instructions on actualizing it (mngon du byed pa'i thabs) and do not cultivate it (ma bsgoms).$^{25}$ Ngor chen's main point in this comparison is that these lower tantras have a fruit that is distinct ('bras bu la khyad yod) from the niruttara tantras, the path of nothing higher (bla na med). The fruit of the lower tantras is slightly inferior (cung zad dman pa yin). ${ }^{26}$

As evidence, Ngor chen cites a passage from Lha mo bzhis zhus kyi grel par, presumably a commentary on the Caturdevīpariprcchā, an explanatory tantra of the Guhyasamāja cycle. In this passage, the Buddha of the Vajrayāna is one with nothing higher because there's no other higher vehicle; this Buddha is pure (yang dag $p a$ ) because of residing in the Mahāyāna. ${ }^{27}$ The Buddha of the sūtra pitaka is grouped together with that of the sbyor $b a^{\prime} i$ rgyud, presumably referring here to yoga tantra and below, as "having a vehicle that's higher" (theg pa gong na yod pa) and therefore "possessed of something higher" (bla dang bcas pa). They are fully perfected or complete (yang dag par rdzogs pa) because, again, they reside in the Mahāyāna. On the other hand, śravakas and pratyekabuddhas "are not fully perfected" (yang dag par rdzogs pa min) because they "have vehicle above them" (theg pa gong na yod pa). In this case to have something above is to be in need of reversal (bzlog dgos pa).

\subsection{The Citation}

Ngor chen punctuates his argument for subtle distinctions in the fruits of the various paths with a citation from the Sems kyi sgrib sbyong, a text attributed to Āryadeva and

23 This citation appears to be from Nāgabodhi's commentary on the Pañcakrama.

Tshul khrims rin chen, "Rim pa lnga pa'i bshad pa nor bu'i phreng ba," in bstan 'gyur (sde dge). TBRC W23703. 37: 29-315.

See Ngor chen, Dispelling Evil Misunderstandings of the Explanation, 683.3-686.1.

24 rab tu gsal zhing dga' ba'i rang bzhin gyi de kho na nyid lhan cig skye pa thob par byed pa ma yin pa'i (685.3) phyir ro. Ngor chen, Dispelling Evil Misunderstandings, 685.2-685.3. I have emended gyis to gyi here.

25 yang gal te/(688.4) phyag rgya chen po bde ba'i ye shes ni/stong pa dang snying rje zung 'jug yin la/de ni rnal 'byor rgyud man chad las kyang gsungs bas na lam mtshungs par'gyur ro.zhe na mi 'gyur te/nyan thos gyi theg par sangs rgyas kyi yon tan sogs bstan kyang/stong nyid (688.5) ma bstan pas/theg chen la khyad par yod pa bzhin/rnal 'byor rgyud man chad du/sangs rgyas kyi bde ba sogs bstan yang/de mngon du byed pa'i thabs ma bstan zhing ma bsgoms pas 'bras bu la khyad yod do. Ngor chen, Dispelling Evil Misunderstandings, 688.3-688.5.

26 de bas na rgyu dman pa'i phyir 'bras bu'ang cung zad dman pa yin te. Ngor chen, Dispelling Evil Misunderstandings, 689.2.

27 See Ngor chen, Dispelling Evil Misunderstandings, 689.2-689.5. 
included in the Tengyur. ${ }^{28}$ In this citation, hierarchies reinforced in the language of progress ascension (with gong ma gong $m a$ ) serve both a pedagogical and soteriological purpose. The passage shows how overcoming a previous mind state or philosophical view is a formative aspect of the learning process, as illustrated by a provisional translation: "Likewise, from the worldly, yogins (i.e., practitioners) conquer worldly beings. By means of a mind that discerns higher and higher (gong ma gong ma'i blo khyad kyis), the yogin is victorious. In the Mahāyāna, there is the correct teaching of great knowledge and great method and great sympathy and the wish. That is the sphere of activity of great beings." 29 Ngor chen builds upon the sense of progress through overcoming, a pedagogical process of advancing higher and higher in Āryadeva's words to assert a "slight distinction in the fruit" ("bras bu la'ang khyad par cung zad). ${ }^{30}$

Ngor chen draws upon this same passage from Āryadeva's text in a tantric polemical treatise he wrote just two years later. In overcoming Objections to the Three Tantras and its autocommentary, Ngor chen opposes the claim that the three Hevajra tantras promoted by the Sakyapas as vital to their Path and Fruit Tradition (these three tantras being the Hevajra root tantra together with the Samputa and Vajrapañjara explanatory tantras) were cittamātrin in orientation. ${ }^{31}$ As I argue in a different article, the text demonstrates the porous boundary of sūtra and tantra in that the very suggestion that the Hevajra tantra is cittamātrin prompts Ngor chen to defend the status of the Hevajra tantra as superior and profound among the Buddha's teachings. (Dachille 2021). His goal to show that the Sakyapa tantric perspective is in sync with the Madhyamaka view on emptiness. Zung 'jug plays a fundamental role in that text as well, specifically in its manifestation in the principle of gsal stong zung 'jug. It is tempting to delve into Ngor chen's rich use of zung 'jug in that text. However, in concluding, I would like to instead briefly introduce how Ngor chen uses this very same citation from Āryadeva's Sems kyi sgrib sbyong within that argument. ${ }^{32}$

Ngor chen suggests that if his opponent's claim were true, it would upend the logic of the order of instruction given by the Hevajra tantra itself: Vaibhāṣika, Sautrāntika, Yogācāra, Madhyamaka and then the teachings of mantra and therefore ultimately the Hevajra tantra. ${ }^{33}$ In other words, if the Hevajra tantra were equivalent to the Yogācāra, it would not make any sense to study Madhyamaka and then once again study a Yogācāran position. Ngor chen problematizes his opponent's view with the citation of the first of those two verses from the Sems kyi sgrib sbyong on the grounds that reversing the order of learning would mean that the practitioner did not continue to ascend through levels of attainment or to overcome (gnod) previous mental states. ${ }^{34}$ The resonance of this citation in these two texts by Ngor chen, both texts directed at least in part at Red mda' ba, texts dealing with different facets of the relationship of sūtra and tantra and, despite Ngor chen's orientation in the Hevajra system, very much engaging with the Ārya Guhyasamāja system, is striking.

28 Tshul khrims rin chen, "Sems kyi sgrib pa rnam par sbyong ba zhes bya ba'i rab tu byed pa," in bstan 'gyur (sde dge). TBRC W23703. 35: 214-25. The citation discussed below appears at 219.3-219.4 of this edition.

29 de bas na sems kyi sgrib sbyong las/ji ltar 'jig rten phal las/rnal (689.6) 'byor pa ni' 'jig rten rgyal. gong ma gong ma'i blo khyad kyis/rnal 'byor pa'ang rgyal bar 'gyur. shes rab che dang thabs che dang/brtse ba che dang mos pa nyid/theg pa chen po yang dag bstan. sems can chen po'i spyod yul yin. Ngor chen, Dispelling Evil Misunderstandings, 689.6 .

30 Ngor chen, Dispelling Evil Misunderstandings, 689.6.

31 Ngor chen Kun dga' bzang po (1382-1456), “Overcoming objections to the Three Tantras” (Rgyud gsum gnod 'joms) in Ngor chen kun dga' bzang po'i $b k a a^{\prime}$ 'bum = The Collected Works of Ngor chen Kun dga' bzang po/compiled by Bsod nams rgya mtsho. Tokyo: Sa skya pa'i bka' 'bum = The Complete works of the great masters of the Sa skya sect of the Tibetan Buddhism; v. 9-10. The Toyo Bunko, 1968-1969, vol. 9: 155d-157a. Ngor chen Kun dga' bzang po (1382-1456), "Commentary on Overcoming Objections to the Three Tantras" (Rgyud gsum gnod 'joms kyi 'grel pa), in Ngor chen kun dga' bzang po'i bka' 'bum, The Toyo Bunko, 1968-1969, vol. 9: 157a-164b.

32 Note that Ngor chen only quotes the first section of the passage in this text. See Ngor chen, Commentary on Overcoming Objections, 161d.2-161d.3

33 For Ngor chen's complete argument on the order of teaching, see Ngor chen, Commentary on Overcoming Objections, 161c.1-161d.3. See also Hevajra Tantra II.viii. v. 10.

34 de lta na ni/dang por grub mtha' 'og ma gnyis la bslab/de nas rnam rig pa la bslabs nas bzod dbu ma bstan de/dbu ma'i lta ba rtogs pa'i gang zag de slar yang rnam rig pa la jug par'gyur te/ rgyud 'di lta ba rnam rig tu gnas shing/dbu ma'i rjes la rgyud 'di la bslab par gsungs pa'i phyir ro. 'dod na dbu ma las rnam rig pa dag khyad par du 'phags par 'gyur zhing/rnal 'byor pa'ang blo khyad kyis/gong ma gong ma rnams kyis gnod par yang mi 'gyur la. Ngor chen, Commentary on Overcoming Objections, 161c.6-161d.2. 
My experience working with Ngor chen's tantric polemical texts, namely the two I discussed here as well as his engagements on body mandala, suggests that concerns with the order of things were bubbling up in his time: concerns with the ranking of the fruits of the paths toward liberation together with their attendant literary and ritual traditions, concerns with pedagogical progressions, as well as with ritual sequences. Ngor chen is responding to a compulsion to relate the stages of tantra with that of the path of perfections, and perhaps to resist some of the attempts to synthesize the paths too neatly. In this final section of the article, I contextualize Ngor chen's efforts to differentiate the fruits of sūtra and tantra within the intellectual history of tantric scholasticism in Tibet.

\subsection{Tibetan Legacies of Differentiation}

Ironically, differentiation is at the heart of clarifying zung 'jug, a state of attainment understood in terms of nondifferentiation. The main thrust of Ngor chen's text is to distinguish the fruits of the tantric path. His main point is that the niruttara yoga tantras are superior among the buddha's teachings ( $r a b$ dang mchog $t u$ gyur) and that the wisdom of the thirteenth ground Vajradhara is the fruit of that. Ngor chen emphasizes the difference between the eleventh ground buddha of perfections and the thirteenth ground zung 'jug Vajradhara.

Ngor chen does however discourage distinguishing and ranking on one count. Ngor chen argues that there is no need to rank the fruits of the three activities of the rnal 'byor bla med tantras in terms of greater and lesser degrees of proliferation. These are the three activities discussed in the CMP: with elaboration, free from elaboration, and totally free from elaboration. Using a metaphor from that text of the burning of trees resulting in ash, Ngor chen argues that there is no need to differentiate the fruits of those activities ('bras bu thal bar dbyer med pa bzhin no). ${ }^{35}$ In the Sngags rims chen mo, Tsong kha pa cites Aryadeva's classification of three activities in terms of the different mindsets of three levels of disciples. (Tsong-kha-pa Blo-bzang-grags-pa 2016, p. 73). This is a common trope in classifying teachings, one that lies at the heart of the genre of "stages of the path" (lam rim), as a quintessential means of ranking the Buddha's teachings. Ngor chen shows little concern with this typology is his own text.

In this section, I highlight key articulations of the relationship of sūtra and tantra relevant for appreciating Ngor chen's contributions to differentiating their fruits. These include references to the writings of Ngor chen's Sakyapa predecessors as well as to Tsong kha pa's concerns with the connection between seeds and fruits. In putting these ideas in conversation, I suggest that differentiation is a mode of exchange operating in tension with synthesis within Tibetan scholasticism. I begin by returning to Red mda' ba's Guhyasamāja commentary to consider how it fails, by Ngor chen's standards, to properly differentiate the paths of sūtra and tantra.

\section{A Singular Meaning (Don Gcig)}

In the section of his critique on the "actual mistaken conceptions" (log rtog dngos) of his opponent, Ngor chen cites some of Red mda' ba's objectionable views verbatim along with a few paraphrases. These remarks derive from a section in Red mda' ba's Yid kyi mun sel devoted to the topic of "apprehending the threshold" (sa mtshams ngos bzung ba) of zung 'jug. ${ }^{36}$ This is one of eight topics Red mda' ba presents to lay out how, "after perfecting the ultimate truth, the non-dual wisdom is to be taught as zung 'jug." ${ }^{37}$ He begins by stating that most Indian and Tibetan masters, including Abhayā and Śāntipa regard the paths of sūtra and tantra as "singular in meaning" (don gcig) but also see the Vajrayāna as superior (khyad par du 'phags pa) because of providing the possibility of enlightenment in this lifetime and this body. ${ }^{38}$ He reinforces the singularity of these approaches with a charged citation

See Ngor chen. Dispelling Evil Misunderstandings, 690.1-690.4.

36 The section extends from 70.3-77.1 of Red mda' ba's text. 72.3-74 matches Ngor chen's citation of the mistaken view almost precisely. See Ngor chen, 660.4-662.3.

37 Red mda' ba, Yid kyi mun sel, 69.6-70.1.

38 Red mda' ba, Yid kyi mun sel, 70.3 . 
from Tripiṭakamāla's Tshul gsum sgron ma: Don gcig na yang ma rmongs dang/thabs mang dka' ba med pa dang/dbang po rnon po'i dbang byas nas/sngags kyi theg pa khyad par 'phags. ${ }^{39}$ The precise meaning of these verses is elusive, but they project of view of a "singular meaning" (don gcig) uniting the paths of sūtra and tantra while asserting the superiority (khyad par 'phags) of the mantrayāna as a vehicle to liberation ideally suited to those endowed with high acumen (dbang po rnon po).

Tripitakamāla's verses have prompted lively debate among Tibetan scholars for centuries. ${ }^{40}$ A number of the sources I consulted to better understand Ngor chen's approach to differentiating sūtra and tantra cite the Indian master's Tshul gsum sgron ma as a precedent. Two of the great Sakya patriarchs provide fruitful examples. In his pithy text outlining the distinctions of sūtra and tantra, the Sakyapa patriarch Sa chen kun dga' snying po expounds upon Tripițakamāla's verses as follows: "Since bodhicitta, emptiness and compassion are the foundation of secret mantra, they are don gcig." ${ }^{41}$ Sa chen details the purificatory, transformative, and blissful methods of mantra in progressing toward the thirteenth ground as the ultimate goal for one who has received the four initiations. Sa chen's descendent, Sa skya Pandita Kun dga' rgyal mtshan (Sa pan) justifies the superiority of tantra in a manner that resonates with those verses as well: "While full enlightenment is identical in the Perfections and Mantra systems in terms of Buddha-bodies, gnoses, and spiritual feats, the Mantra vehicle is superior by virtue of its lack of confusion about methodology, greater variety of techniques, freedom from hardship, and suitability for the keen-witted." ${ }^{42}$

Atiśa Dipamkara (982-1055) established the paradigm for the stages of the path genre after which Tsong kha pa models his own Lam rim chen mo and Sngags rim chen mo. In expounding on the verses on mantra in his Lamp for the Path, Atiśa distinguishes appropriate tantric practice for monastics and prohibits their participation in the higher phases of tantric initiation. Atiśa therefore barred monastics from participating in sexual yoga, although activities such as studying and teaching the tantras and performing fire offerings were permissible. (Atīśa and Sherburne 1983, pp. 174-77). He too, invokes Tripițakamāla in distinguishing sūtra and tantra, using the verse to introduce his commentary on the mantric path. He interprets its meaning as follows: "Hence, the bodhisattva who engages in the practice of Mantra must first produce that unmistakable reality, the Thought of Enlightenment in its ultimate sense." (Atīśa and Sherburne 1983, p. 166). ${ }^{43}$ Atiśa is not interested in elaborating further on the meaning of Tripitakamāla's text, explaining: "Here in my root text I (simply) set down some of the means for accumulating the Two Equipments (of merit and knowledge), for a bodhisattva who is in the Generation Stage, and confine myself to that." In his Sngags rim chen mo, Tsong kha pa describes Tripitakamāla's view as not distinguishing the fruits of the paths and therefore somewhat in line with his own approach, which as I discuss below, prioritizes method and causal relationships over fruits as bases for differentiating the paths. However, he critiques this author's use of four features to set all four classes of tantra as superior to the path of perfections. He identifies these features as: "being unobscured", "having many methods", "having no difficulties", and "being contrived for those with sharp faculties."(Tsong-kha-pa Blo-bzang-grags-pa 2016, p. 133-36).

In introducing the idea of a "singular meaning," Tripițakamāla simultaneously inspires Tibetan authors to synthesize the two aspects of the Mahāyāna as well as to differentiate them. In the next two subsections, I briefly introduce two influential examples of how this dual quality of synthesis and differentiation accompanying the prospect of "singularity"

39 Tshul khrims rin chen, "Tshul gsum gyi sgron ma," in bstan 'gyur (sde dge), TBRC W23703. 78: 14-54. Delhi: Delhi karmapae choedhey, Gyalwae sungrab partun khang, 1982-1985. For citation, see Red mda' ba, Yid kyi mun sel, 70.5-70.6.

40 Drakpa Gyatso, International Buddhist Academy, personal communication, January 2021.

41 Kun dga' snying po, Bsod nams rtse mo, Grags pa rgyal mtshan, Kun dga' rgyal mtshan, Blo gros rgyal mtshan, “Theg pa'i rnam dbye bsdus pa," In Sa skya bka' 'bum. TBRC W00EGS1017151. 15: 532-535. (Kathmandu): Sachen international, 2006.

42 In Reply to the Questions of Dokorwa the Kadampa, translated in (Sa-skya Pandi-ta Kun-dga-rgyal-mtshan et al. 2002, fn1).

43 Sherburne translates Tripitakamāla's verses there as follows: "The teachings on mantra are eminently superior when mastered by one of keen abilities, because of the many Means (they offer) without austerity-provided the one and only Goal is kept, unobscured." He also notes that Atiśa cites this same Indian author at the conclusion of his section on the perfections vehicle. See p183 fn1. 
assumes vibrant forms within the Sakyapa tradition in the centuries leading up to Ngor chen's writings on zung 'jug. These examples occur in the works of Bsod nams rtse mo and his nephew, Sa pan.

\section{The Sakyapa Tantric Perspective}

After citing Tripitakamāla's verses, Red mda' ba summarizes the Sakyapa perspective on the superiority of the fruits of mantra as based on three factors ${ }^{44}$ :

- $\quad$ what they eliminate (spangs pa): the subtle defilement of seeing samsāra and nirvāna as different;

- $\quad$ what they realize (rtogs pa): penetrating the nondual nature of dharmas;

- their transformation (gnas 'gyur): channel body, channels letters, heart wisdom wind, bodhicitta.

According to this view, one should engage in the path of four initiations in reliance upon the "proximate cause" (nye rgyu), meaning in reliance on the consort. Moreover, the eleventh ground is the ground of Buddhahood but not of Vajradhara. A citation from the Samputa Tantra reinforces this point: “One who doesn't obtain the unfathomable abode, they are a tathāgata and the ground of Buddhahood. As for the one exemplifying the characteristics, they are taught to be utterly pure Vajrasattva." ${ }^{\prime 5}$ Ngor chen cites this same verse in the section of his text introducing his own view (rang lugs bzhag pa) as evidence for the major difference (khyad ches che $b a$ ) between the buddhas of the eleventh and thirteenth grounds. ${ }^{46}$ Red mda' ba follows the excerpt from the Samputa with a citation of "Smri ti" that closely aligns with Ngor chen's citation of the Lha mo bzhis zhus kyi grel pa passage discussed above. That passage ranks the teachings in terms of the "existence of something higher" (gong na yod pa), creating a hierarchy with the Buddha of the niruttara tantras at the apex, followed by that of the caryā tantras and sūtras, and finally, the pratekabuddha and śravaka. That passage was crucial for Ngor chen in linking the projects of classifying and stratifying texts and soteriological attainments.

Red mda' ba's summary of the Sakyapa perspective here seems relatively in sync with Ngor chen's views. However, Red mda' ba shifts gears to differentiate his own view by stating: "I realize in accord with the intention of the Ârya fathers and sons" (kho bos ni 'phags pa yab sras kyi dgongs pa'di ltar rtogs te). With this pronouncement, he launches into the objectionable views cited precisely by Ngor chen as the "actual mistaken conceptions" ( $\log r t o g$ dngos). In this way, Red mda' ba distinguishes his own presentation of the paths, diverging from his Sakya forefathers and grafting a new lineage of interpretation inherited from the Indian interpreters of the Guhyasamāja tantra. Red mda' ba concludes his section on "apprehending the threshold" of zung "jug by reinforcing this connection to the Ārya tradition and casting a shadow upon those who fail to fall in line with this interpretation: "As for the threshold of the fruit of the final goal of Vajrayana, a few of us excellently realize based on the tradition of the Ârya masters, but others do not think about it like that." ${ }^{\prime \prime 7}$ My mentor, Drakpa Gyatso suggested that these "others" suggested by Red mda' ba include Sa chen's son, Bsod nams rtse mo. ${ }^{48}$

Within the Sakyapa tradition, Bsod nams rtse mo provided the most influential model for fusing the projects of classifying and stratifying texts and soteriological attainments. His Rgyud sde spyi'i rnam bzhag pa provides an overview of the tantric system as well as of the Mahāyāna more broadly. The title conveys this concern with "classification" (rnam gzhag). In this text, Bsod nams rtse mo introduces the fourfold mode of classifying tantric texts (as kriyā, caryā, yoga, and niruttarayoga) as well as a formative model for presenting

44 See relevant section in Red mda' ba, Yid kyi mun sel, 71.3-71.4.

45 Gang bdag bsam gyis mi khyab pa'i gnas ma thob pa de ni/bde bar gshegs pa ste sangs rgyas kyi sa yin no. mtshan gzhi mtshon par byed pa ni/rdo rje sems dpa' yang dag par gsungs so. Samputa Tantra as cited in Red mda' ba, Yid kyi mun sel, 71.6.

46 See especially Ngor chen, Dispelling Evil Misunderstandings of the Explanation, 674.4-674.3.

47 'phags pa yab sras kyi gzhung la brten nas/ kho bo 'ba' zhig gis legs par rtogs kyi/gzhan dag gis ni ji bzhin bshad par mi sems so. Red mda' ba, Yid kyi mun sel, 76.6-77.1.

48 Drakpa Gyatso, International Buddhist Acedemy, Personal communication, January 2021. 
the stages of attaining the grounds of bodhisattvahood. (Davidson 2005, p. 361). ${ }^{49}$ While he builds on another pity text his father wrote on the "classification" of the tantras, he posits the superiority of the tantric path as based not only on its speed but also its superior fruit. $^{50}$

Singularity posed challenges for Bsod nams rtse mo as well. According to Ronald Davidson, his "doctrine of single Buddhahood required some manipulation of goal-related terminology, for how could there be only one goal for Mahāyānist paths when the esoteric system yields a superior result?" (Davidson 2005, p. 362). Bsod nams rtse mo responded to charges that the Buddhist tantric path is faulty on account of qualities such as its absence of difficulties and its myriad techniques, qualities familiar from Tripițakamāla's verses discussed above. ${ }^{51}$ According to his imagined opponent, these qualities are shared by non-Buddhist schools. The opponent also claims that the tantric path itself is not unique in producing a body of Buddhahood, for the path of perfections too produces that result. For Davidson, Bsod nams rtse mo's maneuvers in this text are evidence that "hermeneutical stratification continued to be the apologetic method of choice" during his time. (Davidson 2005, p. 364) The Sakyapa patriarch applies methods he learned outside the tantric fold under Phywa pa chos kyi seng ge (1109-1169) during his time at Gsang phu. (Davidson 2005, p. 362; Jackson 1996, pp. 235-36). I agree with Davidson's proposal that Bsod nams rtse mo's time there may also have set the conditions for his defense of the Sakyapa tantric perspective. (Davidson 2005, p. 361).

To classify and rank texts and attainments is a charged interpretive act, one that Ngor chen embraces is his reply to Red mda' ba. While Ngor chen is responding to a different set of factors than Bsod nams rtse mo, factors linked with "sectarian differentiation" particular to his time and position, he enters into a compatible project of distinguishing the fruits in promoting the tantric path as superior. Moreover, Ngor chen's acts of differentiation may have included setting his views apart from luminaries of his own tradition, including Bsod nams rtse mo. For example, Bentor suggests that about twenty years after Ngor chen composed this text, Tsong kha pa's disciple Mkhas sgrub rje dge legs dpal bzang (1382-1438) antagonized Ngor chen for diverging from Bsod nams rtse mo's views on the question of whether bodies in their true form are inherently mandalas. (Bentor 2017, p. 237). Mkhas grub presents his claim in a chapter on body mandala within his extensive treatise on the generation stage practices of the Guhyasamāja. Bentor proposes that Mkhas grub is referring here to Ngor chen's remarks in his zung 'jug text. ${ }^{52}$ I translate the relevant section of Mkhas grub's text as follows:

"On the other hand, one who makes claims like that would have to (also) claim that it is totally unnecessary for one who is a Buddha and recognizes oneself as such to cultivate the path. (Based on that) one would have to claim that cultivating the path after encountering the body mandala one time is totally unnecessary. If that's the case, speaking in this manner, one who claims that it's necessary to traverse the grounds and paths in stages while cultivating the path is unstable. Having asserted the "universal illumination," the eleventh (bhūmi), which is explained as the ultimate object of attainment of the path of the Pāramitāyāna, to moreover be inferior to tantric Vajradhara, (such a proponent) establishes all sentient beings as primordially the mandala of Vajradhara. Therefore, matters really

49 Davidson suggests that the influence of his father's work in especially evident in the first chapter of Bsod nams rtse mo's text and that Sa chen's text may itself have been based on one by Mgos khug pa lhas btsas. For Sa pan's text, see Kun dga' snying po, Bsod nams rtse mo, Grags pa rgyal mtshan, Kun dga' rgyal mtshan, Blo gros rgyal mtshan, "Rgyud sde spyi'i rnam par gzhag pa," in Sa skya bka' 'bum/. TBRC W00EGS1017151. 3: 7-164.

Bsod nams rtse mo's tantric classificatory schema also parses the niruttara tantras into "father, mother, and nondual." (Dalton 2005, pp. 159-60). On Bsod nams rtse mo's contributions to the "stages of the doctrine" (bstan rim) genre and his degree of influence upon Sa pan's Thub pa'i dgongs gsal, see (Jackson 1996, pp. 229-43). See especially pp. 235-39.

50 Kun dga' snying po, Bsod nams rtse mo, Grags pa rgyal mtshan, Kun dga' rgyal mtshan, Blo gros rgyal mtshan, “Rgyud sde spyi'i rnam par gzhag pa," in Sa skya bka' 'bum/. TBRC W00EGS1017151. 3: 7-164. (Kathmandu): Sachen international, 2006.

51 I base these remarks on Bsod nams rtse mo's defense on Davidson's assessment in (Davidson 2005, pp. 363-64).

52 (Bentor 2017) refers to a related passage in Ngor chen's text. The equivalent section in the version I use in this article is Ngor chen, Dispelling Evil Misunderstandings of the Explanation, 673.6-674.2. The passage appears at the end of Ngor chen's refutation of the problematic view (de dag dgag). Ngor chen's interpretation of passages from the autocommentary of the Madhyamakāvatāra in this section merits future research. 
become extraordinary. Let us say that based upon the idea that such and such part of the body-mind (composite) of sentient beings is unclear and unmanifest (in relation to) such and such a part of the body mandala from the beginning, you say (it) is actualized by the power of cultivating the path. In claiming by virtue of lack of clarity that it's the case that primordially, all the parts of the fruit are actually in the cause (without being realized), (one's claim) becomes no different than the Samkhya system." ${ }^{\prime 53}$

The logic of a gradual approach to practice, a logic so vital to Tibetan understandings of their own tradition, resounds in Mkhas grub's attack. He suggests a paradox in claiming simultaneously that the fruits of sūtra and tantra are different and that sentient beings are inherently identical with mandala. He punctuates his absurdist argument with a reference to the non-Buddhist Samkhya system as a tradition that fails to parse fruits from their causes. When I initially read Mkhas grub's s body mandala chapter with Khenpo Choying Dorjee of Dzongsar Institute, he described two main approaches to relating the fruits of sūtra and tantra, as either a component of the path or as the "ultimate destination." 54 The first approach, associated with the Sakyapas, posits, as Ngor chen does, that the eleventh ground was a part of the path but that it was necessary to move beyond that level through tantric practice to attain the level of Vajradhara. For figures such as Mkhas grub rje and Tsong kha pa, on the other hand, the eleventh ground is the ground of Vajradhara. This is just one example of the ways in which Ngor chen's text promises to illuminate later exchanges in the intellectual history of differentiating paths and fruits within the genre of tantric polemics.

\section{Differentiation as Liberatory Act}

No one sets the stakes for acts of differentiation higher than Sa pan, who writes: "When one does not discriminate among philosophical systems and does not understand the gradations of tantra, no matter how excellent the system may seem, this is like using a shoe pattern for making a hat." (Sa-skya Pandi-ta Kun-dga-rgyal-mtshan et al. 2002, p. 105 v. 77). Differentiation ( $r a b t u$ dbye ba) is the motivating principle of Sa pan's Clear Differentiation of the Three Codes (Sdom pa gsum gyi ra btu dbye ba). In this text, Sa pan strives to disentangle the three vows that seal the commitment to practice three forms of Buddhist practice: cultivating monastic asceticism to uproot the poisons binding one to samsāric existence, practice motivated by firm altruistic intention to liberate all beings from those conditions of suffering, and initiation and cultivation of a ritual program of approximating oneself with Buddhahood. These three vows correlate with three vehicles for progressing toward enlightenment: the Śrāvakayāna, the Mahāyāna, and the Vajrayāna. Sa pan regarded the unique power of tantric initiation to unite these three vows but retained core differences between them. ${ }^{55}$

For Sa pan, ritual is the primary criteria for distinguishing sūtra and tantra and analysis is essential: "The difference between sūtra and tantra lies in the respective absence or presence of the performance of rites. Having understood this, you should teach the two systems of sūtra and tantra only after having investigated them." (Sa-skya Pandili-ta Kun-dga-rgyal-mtshan et al. 2002, p. 129 v. 252). He promotes a two part program of ripening by four ritual initiations by the guru and liberation by the two stages of sādhana propounded in the niruttara tantras. The rate of ripening is accelerated: "The seeds planted through the mantra system ripen to harvest within a single day. If one knows the techniques of the Vajra Vehicle, Buddhahood will be won in this very lifetime." (Sa-skya Pandi-ta Kun-dga-rgyal-mtshan et al. 2002, p. 111 v. 121). While the path of perfections concludes

53 Mkhas grub rje dge legs dpal bzang (1385-1438), Ocean of Attainment of the Guhyasamāja Generation Stage (Gsang 'dus bskyed rim dngos grub rgya mtsho), New Zhol par khang edition of Gsung 'bum: Mkhas grub rje (zhol). TOH 5481. New Delhi: Mongolian Lama Guru Deva. 1980-1982. BDRC W384, vol. 7, pp. 5-384.

54 Khenpo Choying Dorjee, Personal communication, UC Berkeley, Spring 2011.

55 “Two underlying premises of Sapan's work are that every Buddhist practice can be associated with one of three distinct systems of discipline- the prātimokșa vow of the Śravaka schools, the bodhisattva vow of the Mahāyāna schools, or the vidyādhara vow of the Vajrayāna lineages-and further, that those three are not separate but become, in fact, "of a single nature" through transformation during Vajrayāna initiation." (Sa-skya Pandi-ta Kun-dga-rgyal-mtshan et al. 2002, p. 23). See fn76 \& 77 for further detail on this notion of "single nature" and its relationship to the ideas of Sa pan's predecessors such as Grags pa rgyal mtshan. 
with Buddhahood after demon-quelling in the tenth level of bodhisattvahood, the path of mantra culminates on a higher level: "After traversing all the inward levels and paths, one will attain the thirteenth level, Vajradhara's level of virtue." (Sa-skya Pandi-ta Kun-dgargyal-mtshan et al. 2002, p. 112 v129). However, in the same text, he famously professed that if there is a view higher than that of the perfections it's an "elaboration," meaning it's faulty. ${ }^{56}$

Sa pan's acts of differentiation in this text were largely motivated by yet another manifestation of singularity. The "self-sufficient white remedy" (dkar po chig thub) that arose among the Dwags pa Kagyupas offended Sa pan's sensibilities in a number of ways. Prominent among these were the positing of a singular means for attaining enlightenment and the practice of introducing the Great Seal instructions outside of the tantric context and even as a separate modality outside of the paths of both sütra and tantra. Sa pan provoked lively debates on the topic of $d k a r$ po chig thub that assumed momentum centuries later. (Jackson 1994).

Like Ngor chen, Sa pan may have been reacting to a variety of syncretism emerging among Tibetan Buddhists of his time, in particular "more syncretic Tibetan presentations of the three sets of vows, which stressed their single import or nature but minimized their differences." (Sa-skya Panḍi-ta Kun-dga-rgyal-mtshan et al. 2002, p. 5).

On Seeds and Fruits

At moments in his quintessential stages of the path text, the Sngags rims chen mo, Tsong kha pa appears equally concerned to articulate criteria that do not qualify as grounds for differentiating the two vehicles as to articulate those that do. For example, he accepts the diversity of forms of "pleasure" described by the Samputa Tantra as "laughing, gazing, holding hands, embracing" as well as their correspondence with the different practitioners of the four classes of tantra; however, he does not regard these desirous activities as useful for distinguishing sūtra and tantra. (Tsong-kha-pa Blo-bzang-grags-pa 2016, p. 95) Likewise, he rejects the criterion of whether one is "adorned with bliss" because the most profound bliss only occurs in the niruttara class of tantras; he also rejects a basis in "whether concentration occurs on essential points of the body and mind" as an insufficient criterion for distinguishing the two vehicles, for even non-Buddhists experience many of the blissful states of mediation. (Tsong-kha-pa Blo-bzang-grags-pa 2016, pp. 95-96). The Vajrayāna is widely praised for its expediency. However, for Tsong kha pa, speed is one of a number of qualities attributed to the tantric path as a whole that belong exclusively to the niruttara tantras (Tsong-kha-pa Blo-bzang-grags-pa 2016, p. 131). ${ }^{57}$

Ultimately, Tsong kha pa is more interested in differentiating seeds than fruits, the causes rather than effects of pursuing the paths of sūtra and tantra. While he regards engagement in tantric practice as essential, he resists ranking the two paths in terms of their fruits. For example, he writes "though the paths differ, their fruits do not differ as to superiority and inferiority ... because the objects of attainment for both paths are equally the Buddhahood that is an extinguishment of all defects and a completion of all auspicious qualities." (Tsong-kha-pa Blo-bzang-grags-pa 2016, pp. 96-97). He presents both paths as united by an understanding of emptiness, a compassionate mindset, and a grounding in the perfecting the qualities of the bodhisattva. (Tsong-kha-pa Blo-bzang-grags-pa 2016, p. 97). If tantra is superior in any way, it is in terms primarily of method. He emphatically distinguishes their methods in relation to enlightened corporeality. The path of sūtra lacks a crucial component of contemplative techniques "that are similar in aspect to a Form body adorned with the marks and beauties" and is consequently "incomplete." (Tsong-kha-pa Blo-bzang-grags-pa 2016, pp. 98 and 104).

Tsong kha pa's view of the uniqueness of the tantric path rests on a particular approach to causality, to the relationships of seeds and fruits and the nature of their ripening. For

56 I am grateful to Drakpa Gyatso for bringing this verse to my attention. Komarovski also cites and translates the verse in (Komarovski 2016, p. 150 \& fn23).

57 Tsong kha pa likewise critiques Ratnarakṣita's perspective as one in which qualities belonging only to highest yoga tantra are erroneously used to distinguish sūtra from tantra as a whole. See (Tsong-kha-pa Blo-bzang-grags-pa 2016, p. 132). 
a tantric practitioner destined to be enlightened in this lifetime is not born looking like a buddha: "Therefore, marks and beauties of their own body cannot be posited as acting as causes of marks and beauties of a Form Body; hence, through meditation they must newly achieve in this life a cause that is similar in type to the marks and beauties, and this moreover is not feasible other than through deity yoga." (Tsong-kha-pa Blo-bzang-grags-pa 2016, p. 123). Therefore, the core tantric ritual act of imagining oneself as a buddha is unique in generating a "cause of similar type" (rigs mthun gyi rgyu) to the desired result of the form body of a Buddha. (Tsong-kha-pa Blo-bzang-grags-pa 2016, pp. 122-23). However, for Tsong kha pa there is a crucial distinction between this similar-in-type cause and the cause of "maturation" (rnam smin gyi rgyu). Tantric acts of imagination provide the sole source of seeds of an embodied manifestation of Buddhahood.

Red mda' ba too suggests that causality is significant for understanding the tantric path. The author argues that a "pure fruit," an intangible (thogs med) body cannot arise from a tangible (thogs bcas) cause. He resists an alchemical view of tantric transformation, focusing instead on the idea that the impure body must be cast off in attaining Buddhahood. ${ }^{58}$ Ngor chen staunchly disagrees on this point, extracting quotations from Red mda' ba 's treasured Guhyasamāja as evidence. For example, he cites the Sandhi Vyakarana as follows: "By engaging the being of mantra, that becomes superior. By the attributes of alchemy, metal is made into gold. Likewise, by that of mantra a person is made into a buddha.' So (your view) would contradict that quote." 59 The possible of fruition in this lifetime is central to Ngor chen's foundation in the Sakyapa Path and Fruit (lam 'bras) Teachings.

\section{Materials and Methods}

I have based this study upon the practice of translating Ngor chen's text from Tibetan to English in conversation with Buddhist experts. I also engage rigorously with recent scholarship on tantric polemics, the Sakya tradition, and the paths and grounds of the Buddhist path.

\section{Conclusions}

\section{Conclusion: Ripening the Fruits of Liberation}

The Path and Fruit tradition organizes the quest for liberation in terms of a cause, a path, and a fruit or result. Just as these three are differentiated, they also have a fluid relationship. Somewhat uniquely, the fruit exists even in the path. The fruit is the moment when "obscurations are removed through the practice of the path, the naturally present enlightened state is recognized." (Stearns 2001, pp. 12-13). ${ }^{60}$ Moreover, the path is divided into two parts, the phases of "ripening" and of "liberation." Through initiation and subsequent practice, the tantric adept is liberated. Ngor chen is firmly embedded in this fructive model for attaining enlightenment in this lifetime and this body. ${ }^{61}$

Ngor chen concludes his text by reconciling the two Mahāyāna paths in the wake of his acts of differentiation. He writes: "In short, there is no path of mantra without the previous practice of the path of perfections, but without relying upon the path of mantra one does not attain the fruit of the thirteenth ground." 62 While the path of sūtra is encompassed by the tantric path, tantric practice is essential for fruition, a result embodied in the Vajradhara of the thirteenth bhūmi.

I have illuminated the ways in which Ngor chen's work represents key aspects of ritual, exegesis, socio-politics, and pedagogy relevant for better understanding fifteenthcentury Tibetan scholasticism. To review those findings, engaging in the ritual practices of sexual yoga based in the niruttara tantras, those "with nothing higher" (bla med), is

\footnotetext{
58 I address the implications of Ngor chen and Red mda' ba's exchange for understandings of tantric corporeality in greater depth in a future article.

59 Cited in Ngor chen, Dispelling Evil Misunderstandings, 666.5-666.6.

60 Stearns translates key texts of the Path and Fruit in (Stearns 2006).

61 On Ngor chen's contributions to the textual legacy of the Path and Fruit, see (Sobisch 2008).

62 mdor na pha rol tu phyin pa'i lam sngon du ma song ba'i sngags kyi (691.3) lam med pa sngags lam bsten par 'bras bu sa bcu gsum pa thob pa med do. Ngor chen, Dispelling Evil Misunderstandings, 691.2-191.3.
} 
imperative for liberation. Moreover, differentiation is both an exegetical and soteriological strategy, as is apparent in the analysis of Āryadeva's CMP. Ngor chen's motivations for writing his text also intersect with a rising prominence of the Guhyasamāja as a site for synthesizing sūtra and tantra and for distinguishing traditions, a phenomenon evident in the works of Red mda' ba and Tsong kha pa, and later, of Mkhas grub rje. Finally, in articulating the stage of $m i$ slob and in discerning "perfected" from "fully perfected" buddhahood, Ngor chen presents valuable lessons for what it means to be "done" with the project of learning. My own mentor provided the example of moving from an earlier phases of schooling on to university; just because you graduate does not mean you are done learning. ${ }^{63}$ Buddhist pedagogical models suggest that casting off inferior views is vital both for the learning process and the polemical project. To begin to teach is to embark on a new phase of learning, to gain certainty in a horizon of possibility and of not turning back, without falling into a complacent sense of having "arrived."

In closing, Ngor chen's text enriches our appreciation of the polemical dimensions of "running the numbers" for the tantric path as they relate to broader Buddhist impulses to enumerate the stages of the path to liberation. Ngor chen's use of numbers suggests that the boundary between distinguishing and ranking, classification and hierarchy, is quickly traversed in promoting a picture of the paths to liberation that is not just different, but also better.

Funding: This research was funded by a College of Humanities Faculty Research Grant from the University of Arizona.

Acknowledgments: I deeply appreciate the mentorship of Drakpa Gyatso of the International Buddhist Academy in reading this text with me. I assume responsibility for any faulty interpretations as my own. I benefitted from the support of a College of Humanities Faculty Research Grant from the University of Arizona in completing this research. I am grateful to Kurt Keutzer and Karma Gongde for their help in obtaining versions of Red mda' ba 's text and to Alexander Hsu for inspiring me to explore numbers as a category of analysis in Buddhist texts. I was fortunate to present phases of this research at the 2019 meeting of the Society for Tantric Studies as well as for the 2020 annual meeting of the American Academy of Religion.

Conflicts of Interest: The authors declare no conflict of interest. The funders had no role in the design of the study; in the collection, analyses, or interpretation of data; in the writing of the manuscript, or in the decision to publish the results.

\section{References}

Atīśa, and Richard Sherburne. 1983. A Lamp for the Path and Commentary of Atīsá. London: Allen \& Unwin.

Bentor, Yael. 2016. Divergent Perspectives on the Guhyasamaja Sadhana in Tibet: Dge lugs vs. Sa skya. Journal of Esoteric Buddhism 2016: 70-44.

Bentor, Yael. 2017. Did mKhas grub rje Challenge the Authenticity of the Sa Skya Lam 'bras Tradition? In Towards a History of 15th Century Tibet: Cultural Blossoming, Religious Fervour and Political Unrest. Edited by Volker Caumanns and Marta Sernisi. Lumbini: Lumbini International Research Institute, pp. 227-48.

Buswell, Robert E., and Robert M. Gimello. 1992. Paths to Liberation: The Mārga and Its Transformations in Buddhist Thought. Honolulu: University of Hawaii Press.

Buswell, Robert E., and Donald S. Lopez, eds. 2013. The Princeton Dictionary of Buddhism. Princeton: Princeton University Press.

Dachille, Rae. 2021. Empty Like the Sky': Polysemy and the Problem of 'Mere Clear Awareness' at the Intersection of Sūtra and Tantra in Fifteenth-Century Tibet. Revue D'Etudes Tibétaines. in press.

Dachille, Rae. 2019. Sites of Contagion: Tantric Polemics in Distinguishing the Sakyapa and Gelukpa Traditions of Fifteenth-Century Tibet. Paper presented at the Fifteenth Seminar of the International Association of Tibetan Studies, International Institute of Languages and Civilizations, Paris, France, July 7-13.

Dalton, Catherine. 2019. Enacting Perfection: Buddhajñānapāda's Vision of a Tantric Buddhist World. Ph.D. dissertation, UC Berkeley, Berkeley, CA, USA.

Dalton, Jacob P. 2005. A Crisis of Doxography: How Tibetans organized Tantra during the 8th-12th Centuries. Journal of the International Association of Buddhist Studies 28: 115-81.

63 Drakpa Gyatso, International Buddhist Academy, Personal communication, January 2021. 
Davidson, Ronald M. 1991. Reflections on the Maheśvara Subjugation Myth: Indic Materials, Sa skya pa apologetics, and the birth of Heruka. Journal of the International Association of Buddhist Studies 14: 197-235.

Davidson, Ronald M. 2002. Reframing Sahaja: Genre, Representation, Ritual and Lineage. Journal of Indian Philosophy 30: 45-83. [CrossRef]

Davidson, Ronald M. 2005. Tibetan Renaissance: Tantric Buddhism in the Rebirth of Tibetan Culture. New York: Columbia University Press.

Dhammajoti, Kuala Lumpur. 2015. Sarvāstivāda Abhidharma. Hong Kong: The Buddha-Dharma Centre of Hong Kong.

Drewes, David. 2018. The Forest Hypothesis. In Setting Out on the Great Way: Essays on Early Mahāyāna Buddhism. Edited by Paul M. Harrison. London: Equinox Publishing Ltd.

Gethin, Rupert. 1998. The Foundations of Buddhism. Oxford: Oxford University Press USA-OSO.

Go-rams-pa Bsod-nams-sen-ge, José Ignacio Cabezón, and Lobsang Dargyay. 2007. Freedom from Extremes: Gorampa's "Distinguishing the Views" and the Polemics of Emptiness. Boston: Wisdom Publications.

Harter, Pierre-Julien. 2011. Doxography and Philosophy: The Usage and Significance of School Denominations in Red mda' ba gzhon nus blo gros' Ornament of the Proofs of Consciousness. Revue d'Etudes Tibétaines 22: 93-119.

Heimbel, Jörg. 2017. Vajradhara in Human Form: The Life and Times of Ngor chen Kun dga' bzang po. Nepal: Lumbini International Research Institute.

Jackson, David. 1994. Enlightenment by a Single Means: Tibetan Controversies on the "Self-Sufficient White Remedy" (dkar po chig thub). Wien: Verlag der Österreichischen Akademie der Wissenschaften.

Jackson, David. T. 1996. he bsTan rim ("Stages of the Doctrine”) and Similar Graded Expositions of the Bodhisattva's Path. In Tibetan Literature: Studies in Genre. Edited by José Cabezón and Roger Jackson. Ithaca: Snow Lion, pp. 229-43.

Jorden, Ngawang. 2005. Buddha-Nature: Through the Eyes of Go rams pa Bsod Nams Seng ge in Fifteenth-Century Tibet. Ph.D. thesis, University of Chicago, Chicago, IL, USA.

Kassor, Constance. 2011. Gorampa Sonam Senge on the Refutation of the Four Extremes. Revue d'Etudes Tibétaines 22: 121-36.

Komarovski, Yaroslav. 2011. Visions of Unity: The Golden Pandita Shakya Chokden's New Interpretation of Yogacara and Madhyamaka. Albany: State University of New York Press.

Komarovski, Yaroslav. 2016. If Apprehending Occurs, It Is Not the View': Sakya Thinkers on the Madhyamaka View of Freedom from Proliferations. Lincoln: DigitalCommons@University of Nebraska.

Lamotte, Etienne, Sara Boin-Webb, and Kumāraj̄̄va. 2003. Śūraṃamasamādhisūtra = The Concentration of Heroic Progress: An Early Mahāyāna Buddhist Scripture. Delhi: Motilal Banarsidass.

Repo, Joona. 2021. Tsongkhapa Lobzang Drakpa. Treasury of Lives. Available online: http://treasuryoflives.org/biographies/view/ Tsongkhapa-Lobzang-Drakpa/8986 (accessed on 12 January 2021).

Roloff, Carola. 2009. Red mda' ba: Buddhist Yogi-Scholar of the Fourteenth Century. The Forgotten Reviver of Madhyamaka Philosophy in Tibet. Wiesbaden: Dr Ludwig Reichert Verlag.

Sa-skya Pạ̣i-ta Kun-dga-rgyal-mtshan, Jared Rhoton, and Victoria R. M. Scott. 2002. A Clear Differentiation of the Three Codes: Essential Distinctions Among the Individual Liberation, Great Vehicle, and Tantric Systems ...; Six Letters. New York: State University of New York Press.

Sobisch, Jan-Ulrich. 2008. Hevajra and Lam 'bras Literature of India and Tibet as Seen through the Eyes of A-mes-zhabs. Wiesbaden: Reichert. Stearns, Cyrus. 2001. Luminous Lives: The Story of the Early Masters of the Lam'bras Tradition in Tibet. Boston: Wisdom Publications. Cyrus Stearns, trans. 2006, Taking the Result as the Path: Core Teachings of the Sakya Lamdré Tradition. Boston: Wisdom Publications.

Tomabechi, Toru. 2000. Notes on Robert Thurman's translation of the Pañcakrama. Journal of Indian Philosophy 28: 531-48. [CrossRef] Tsong-kha-pa Blo-bzang-grags-pa. 2016. The Great Exposition of Secret Mantra. Boulder: Snow Lion, vol. 1.

Wedemeyer, Christian, and Āryadeva. 2007. Lamp That Integrates the Practices (Caryāmelāpakapradīpa): The Gradual Path of Vajrayāna Buddhism According to the Esoteric Community Noble Tradition. New York: Columbia University Press. 